Bożena Kucała*

\section{The Cold War and the Battle of the Books}

DOI: http://dx.doi.org/10.12775/LC.2020.044

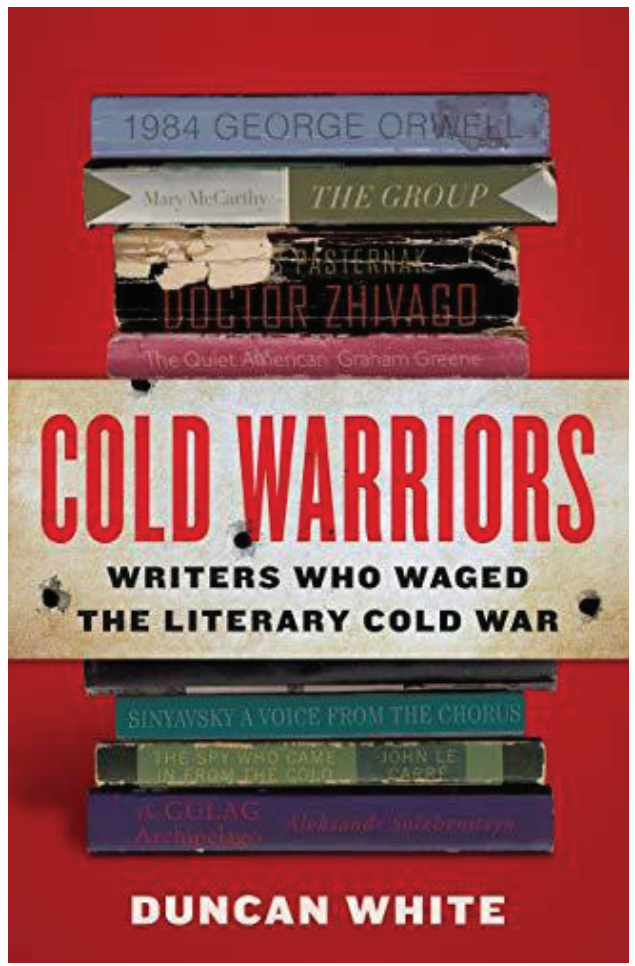

I

$\mathrm{n}$ The Battle of the Books (1704) Jonathan Swift satirised the current "quarrel of the Ancients and the Moderns" by dramatising it as quasi-military combat between books

* Associate professor at the Institute of English Studies, Jagiellonian University in Kraków. Her research interests include the contemporary British novel, especially neo-Victorian fiction and historical fiction.

E-mail: bozena.kucala@uj.edu.pl | ORCID: 00000002-9882-9305. animated by the spirits of their authors, and fought on the premises of the venerated St James's library. "In these books", asserts the narrator, "is wonderfully instilled and preserved the spirit of each warrior, while he is alive; and after his death his soul transmigrates there to inform them" (1933: 545). Duncan White begins his book on literature from the time of the Cold War by invoking a similarly outlandish incident, which, however, was no literary fiction: in 1955 CIA agents penetrated the Iron Curtain by sending balloons loaded with copies of George Orwell's Animal Farm from the territory of West Germany to Poland. However bizarre the idea may seem from the twentyfirst century vantage point, the episode effectively illustrates the tangible power that writers wielded, whether for good or ill, during several decades of twentieth-century history ${ }^{1}$. This was a phenomenon which, White claims, is unlikely to be repeated.

As Giles Scott-Smith and Joes Segal write, "[t] he Cultural Cold War" is a "well established research area” (2012: 4). Duncan White contributes to it in his dual capacity as a historian and a literary scholar. Educated in England, he moved to the United States where he is currently Assistant Director in the History and Literature Department at Harvard University, his special interest being the Cold War. His first book-length study was devoted to the Russian émigré writer Nabokov, Nabokov and his Books: Between Late Modernism and the Literary Marketplace (2017). White's most recent monumental work, Cold Warriors: Writers Who Waged the Literary Cold

1 Cf. The Battle of the Books: "Now, it must here be understood, that ink is the great missive weapon in all battles of the learned, which, conveyed through a sort of engine called a quill, infinite numbers of these are darted at the enemy, by the valiant on each side, with equal skill and violence, as if it were an engagement of porcupines" (Swift 1933: 544). 
War (2019), is a thoroughly researched, over 700-page extensive account of writers' (both intentional and unintentional) involvement in the ideological struggles, and occasionally even their direct participation in the military or espionage activities which are subsumed under the comprehensive term "cold war". Few realise that the metaphor itself, which has gained such widespread currency, was coined by a writer, George Orwell, one of the most engaged literary "warriors".

Although it obviously had its military front, mostly fought outside Europe, the Cold War was primarily "a clash between cultures and ideologies" (Scott-Smith and Segal 2012: 1), or "a conflict of ideas" (White 2019: 2), in which literature could and did play a significant role, based on its potential to influence numerous minds. White's study is no naive glorification of literature, however; the author sets out to demonstrate the multiple uses to which fiction and poetry were put in the battle of ideas, either deliberately by the writers themselves, or by the governments or organisations which controlled the publication and distribution of books. Literature is a double-edged weapon: it was recognised that it can persuade, spread propaganda, distort, or, conversely, convey the truth. Accordingly, certain books gained popularity of their own accord because they genuinely resonated with the readers, while others were promoted and sponsored (overtly or covertly) by political institutions. Of course, the obverse of the picture was the silencing and suppressing of authors deemed subversive or politically dangerous. Behind the Iron Curtain, the suppression took much more malignant forms, including the actual killing of a number of outstanding writers in the Soviet Union. White devotes two chapters of his book to the tragic lot of Isaac Babel, a victim of a show trial, who subsequently perished in a gulag. $\mathrm{He}$ quotes another high-profile Stalinist victim, Osip Mandelstam, as asserting that the attempt at killing poetry, paradoxically, testifies to its power (qtd. in White 2019: 3-4). Yet, by discussing the harassment of writers behind the Iron Curtain, White shows again and again that the purges and other forms of suppression resulted in the physical destruction of manuscripts as well as the annihilation of potential works that eventually were never written. Indeed, the battle of the books was so intense that not only the ideological content but even the literary form tended to be assessed in terms of political criteria. The opposition between realism (or its perverse and not very realistic variation known as "socialist realism") and experiment became politicised, too. Ironically, a writer as avowedly apolitical as James Joyce was inadvertently drawn into the conflict - twelve years after its publication, Ulysses (1922) was singled out for attack during the First Congress of the Union of Soviet Writers (ibid.: 91).

White's study aims to substantiate his claim that the Cold War arms race was paralleled by a "book race" (ibid.: 6). The author traces its origins as far back as the consolidation of Communist power in the Soviet Union in the 1930s, which, on the Soviet side, gave rise to an intense campaign of pro-Communist and pro-Soviet propaganda, calculated to influence both domestic and international audiences. Yet a true race started only at the time of the Second World War, when the United States also acknowledged the value of literature as an ideological tool. State-funded programmes helped to circulate and promote chosen books. The CIA acted as the clandestine subsidiser of a number of books banned in Eastern Europe. White's account of how the manuscript of Doctor Zhivago was smuggled out of the Soviet Union, 
translated, published and distributed in key locations in Europe, as well as how Russian copies of the book were smuggled back to the Soviet Union makes a captivating story, worthy of sensational fiction. A CIA memo recognised that "This book has great propaganda value" (ibid.: 402). The Zhivago operation, under the code name AEDINOSAUR, was one of the most ambitious literary projects launched by the CIA in the 1950s, and it also involved promoting the author as a Nobel Prize candidate.

Literary prizes, most notably the Nobel Prize, were frequently a site of ideological war and conflicting interests or pressures. For example, in 1958 Boris Pasternak won at the expense of his compatriot, the Sovietbacked Mikhail Sholokhov. Likewise, the Prize awarded to Solzhenitsyn not only acknowledged his literary merit, but was undoubtedly a gesture of support for a writer who uncompromisingly revealed the truth about the gulags. Typically, there would be a reversed correspondence between a writer's fame and popularity on one side of the political divide and his or her condemnation or banishment on the other side. The career of the American writer Howard Fast, detailed in Cold Warriors, is a case in point. Initially a staunch Communist, Fast was the author of popular novels which took a critical look at American social and political history. In the era of McCarthyism, the writer was subjected to harassment and surveillance; his novels were among the first to be removed from overseas American libraries when a directive was passed to ban books considered anti-American. In response to his troubles at home, the Soviet Union celebrated him by translating and publishing all of his books, and even making some of them required reading in Soviet schools. In 1953 he was honoured with the Stalin Prize and an appearance on the cover of Pravda. A few years later, after Khrushchev's speech and the invasion of Hungary, Fast had his moment of illumination; he condemned Communism and gradually reasserted his place in mainstream American literature.

Unfortunately, Czesław Miłosz is not discussed in the context of the non-literary impact of literary prizes, although his own Nobel Prize helped to draw attention to the problem of the persecution and suppression of writers for political reasons. He is mentioned only in passing as the author of The Captive Mind (the translation of which is supposed to have been sponsored by the American State Department [ibid.: 7]), and this, together with a brief reference to the Kultura journal, is the only attention that Polish post-WWII literature has been accorded.

White's book, despite its impressively broad scope and abundance of detail, has its limitations and omissions. It focuses in the main on British, American and Russian writers as representative of the two sides of the Iron Curtain (obviously, with the implicit proviso that nationality or location need not be automatically taken to indicate a given writer's political allegiance). This selection effectively makes non-Russian Eastern and Central European literatures a huge blank on the literary map. The only exception is Václav Havel², whose life and career are discussed in a separate chapter placed in the final section of the book. The only non-European and non-US writer examined in detail in the book is the Nicaraguan author Gioconda Belli. The story of Belli's relentless political activity serves as an extended illustration of the fact that the conflict between the world's power blocks had its reflection and counterpart in other parts of the world. Belli's success as a poet was

2 The book also features Arthur Koestler, a Hungarian by birth. However, Koestler spent nearly all his adult life in the West, and even switched to writing in English. 
counterpointed by highs and lows in her political struggle, and in this respect her political career resembled the veering and perilous paths of other literary "cold warriors".

In addition to the two geographical outsiders, Havel and Belli, White's study of "cold warriors" includes separate chapters on the American writers Mary McCarthy, Ernest Hemingway, Howard Fast and Richard Wright, the British authors George Orwell, Stephen Spender, Graham Greene, John le Carré and the Hungarian-British Arthur Koestler, as well as Isaac Babel, Anna Akhmatova, Boris Pasternak, Aleksandr Solzhenitsyn and Andrei Sinyavsky, representing the other side of the Iron Curtain. Apart from the main players, the book makes reference to a great many other writers whose lives intersected with the frontline warriors.

The selection is limited in number but cohesive. The term "warrior" is meaningful: the category includes writers who directly and actively participated in the cultural and political warfare; indeed, some found themselves on actual battlefields. In telling the history of the literary Cold War, White goes back further than one would perhaps expect - to the war in Spain in the late 1930s, which, apart from being a violent and brutal military conflict, was universally perceived as a struggle between rival ideologies. In this sense it predated and foreshadowed not only the Second World War but also the postwar battle of ideas.

The choice of names does not come as a surprise. The Spanish prequel to the Cold War is illustrated with the biographies of three of the most famous foreign writers who joined the International Brigades to fight fascism, and in the course of their harrowing experiences discovered that the complexities of the power struggle belied their initial, uncomplicatedly binary visions. In its very dramatic opening part, the book recounts George Orwell's, Arthur Koestler's and Stephen Spender's encounters with death and their nearly miraculous survival, which was followed by other, less dangerous but equally passionate forms of political commitment. Orwell, Koestler and Spender moved to positions of outspoken anti-Communism; the impact of Animal Farm and Nineteen Eighty-Four made Orwell an iconic anti-totalitarian writer. Ironically, however, his books were suppressed not only behind the Iron Curtain but also in the Western world; in his own review of Cold Warriors, David Pryce-Jones commends White for vividly recreating and evidencing the state of consciousness among Orwell's contemporaries: "it still comes as a shock to remember that publishers rejected all of [his articles on Spain and Homage to Catalonia] for fear of offending the Left" (2019: 39).

White seems to be especially interested in writers whose ideas and allegiances fluctuated, who faced difficult ethical choices, who occasionally found themselves coerced or manoeuvred into complicity, compromises or betrayals. For example, it took Koestler several years to shake off his Communist delusions completely. He left the Communist Party already in 1938, but did so in secret in order not to damage the Communist cause - an action which his biographer Michael Scammel described as "ethically dubious and confused in its reasoning" (qtd. in White 2019: 82). In the Soviet Union, writers faced an enforced choice between freedom or long-term imprisonment, or even a choice between life and death. The most tragic story recounted in Cold Warriors is that of Isaac Babel. Imprisoned by the NKVD, intimidated and tortured, Babel confessed to absurd crimes and even implicated some of his friends. During the trial, he tried to fight back and withdraw some of his testimony, but of course to no avail. Anna Akhmatova's defiance of the authorities was compromised when her son was 
arrested. To save him, she published a cycle of poems, "In Praise of Peace", extolling Stalin's restoration of the Soviet Union after the war. This act of self-abasement, however, for a long time went unrewarded - her son was released only after Stalin's death, and Akhmatova eventually received the dubious praise of being a "true Soviet patriot" (ibid.: 359).

The majority of White's literary heroes lived on "the dangerous edge of things" like characters in Graham Greene's fiction, himself one of the writers portrayed in Cold Warriors. Commenting on the phrase he borrowed from Robert Browning, Greene explained: “'The dangerous edge of things' remains what it always has been - the narrow boundary between loyalty and disloyalty, between fidelity and infidelity, the mind's contradictions, the paradox one carries within oneself. This is what men are made of" (qtd. in Ker 2003: 122) ${ }^{3}$.

Greene's own career is of course a good illustration of internal contradictions, as well as dangerous living. His novels were published in parallel to and usually as a reflection of his engagements in both private affairs and great politics. At the instigation of his sister, he was recruited by the Secret Intelligence Service, despite doubts over his youthful Communist leanings. During the war Greene was posted to Sierra Leone (the setting of his novel The Heart of the Matter [1948]). White suggests that " $\mathrm{t}]$ he service represented an exciting way for Greene to avoid enlisting while earning good money" (2019: 152). Greene's espionage work, journalism, and his keen interest in political conflicts took him to trouble spots all over the world. Drawing on Norman Sherry's biography of the writer, White vividly recounts Greene's trek across the Malayan

\footnotetext{
3 The phrase comes from Browning's poem "Bishop Brougham's Apology".
}

jungle, together with a unit of Ghurkhas the main allies of the British forces fighting against Communist insurgents. But, again, White claims that there were personal motives behind this expedition: "Pushing himself to the limit was the reason Greene was in Malaya. He found himself in the grip of a depression that only danger appeared to lift. From his schoolboy days, when he claimed to have played Russian roulette, he had deliberately placed himself in dangerous situations" (ibid.: 330). Greene's professional political allegiance did not prevent him from appreciating the complexities of the conflicts he witnessed (e.g. the colonial dimension to the East-West conflict outside Europe), and did not diminish his sensitivity to cruelty, suffering and human misery, to which he devoted much attention in his fiction. It is not clear whether he had suspicions about Kim Philby, his superior in the intelligence service, but he could be quite perceptive on other occasions. After a journey to Vietnam, he published The Quiet American (1955), a novel which correctly predicted American involvement in Indochina. Ironically, a novel written by a British spy was widely criticised in the United States as anti-American, and highly praised in the Soviet Union for the same reason (ibid.: 346).

Cold Warriors offers numerous examples of writers' alternate "blindness and insight" (to use Paul de Man's formulation). Genuine commitment to a cause and good intentions did not always go hand in hand with sufficient knowledge and experience. A number of writers in the West failed to understand what the Moscow Trials actually were, and many fell for the Soviet propaganda concerning Trotsky; about fifty intellectuals signed an open letter condemning those who raised doubts about Trotsky's guilt (ibid.: 109). Mary McCarthy was a committed left-wing novelist, but 
from the beginning kept a sceptical distance from the Stalinist version of Communism. She was a member of the group which infiltrated the pro-Soviet Scientific and Cultural Conference for World Peace in New York in 1949 (a follow-up to the World Congress of Intellectuals in Defence of Peace, hosted in Wrocław the previous year), accusing its participants of hypocrisy (ibid.: 229). The Conference was one of numerous collective actions undertaken by intellectuals in response to the crises of the Cold War. In 1937 a questionnaire was circulated among writers to find out their stance on the war in Spain (Authors Take Sides on the Spanish War); several decades later a similar survey among authors around the world aimed to fathom their attitudes to the Vietnam War. On that occasion Auden, who had held radical views in the 1930s, expressed reservations about the project, saying that "literary talent and political common sense rarely go together" (qtd. ibid.: 506). Mary McCarthy, with a record of several decades of political commitment, again felt compelled to act, this time to condemn the American invasion. Not stopping at making public statements, she went to Vietnam as a war correspondent, despite having no previous experience of this kind but convinced that novelists could offer a special perspective. She sent dispatches exposing American atrocities, but at the same time wrote adulatory reports from North Vietnam, taking at face value what she was shown and told by representatives of the regime (ibid.: 519).

As White explains, the detailed accounts of the lives of writers such as McCarthy or Greene, included in his book, help to trace the timeline of the Cold War over several decades. Other writers, to whom less space has been devoted, have been selected due to the important role they played at a particular stage - for example Havel as the actual leader of the Velvet Revolution in Czechoslovakia, a dissident and a persecuted writer turned president. There is one name which stands out, however. Kim Philby, the most notorious double agent of the Cold War, was not a literary figure, but, as White argues, he is portrayed in the book on account of the fact that his career in lies and deception illuminates very well the overlap between espionage and literary fiction (ibid.: 11). Indeed, le Carré (the pen name of David Cornwell) and Greene based their popular spy novels on their own experience of working for British intelligence. Greene made use of his creative imagination in both spheres. The writer in him concocted fanciful spying schemes; among other things, during his African posting he came up with the idea of a bogus rescue of a left-wing agitator by British agents acting as Communist agents, and the subsequent exploitation of the man as a "Soviet" but in fact British spy (ibid.: 155). Greene readers will remember the bizarre plot in Our Man in Havana (1958), in which a vacuum cleaner salesman, and covertly a hapless British spy, due to his lack of achievements sends phoney reports about secret installations using drawings of vacuum cleaner parts, thus causing quite a stir in the intelligence services. However, White demonstrates in his overview that Greene did encounter absurd situations comparable to this in the course of his espionage career.

For the most part, Cold Warriors is not based on original research but on very extensive, in-depth study and a masterly compilation of a great variety of histories of the Cold War, biographies, memoirs and other documents; it also contains numerous references to literary works. The originality of the book consists primarily in the arrangement of the material, which, irrespective of the omissions mentioned above, consolidates into a comprehensive overview of the intersections and mutual influences between 
literature, history and politics over several decades. Within its parts, particular chapters shift back and forth between writers and places. The book is effectively a vivid, fascinating history of the entire Cold War unfolding as parallel or crisscrossing literary biographies. The author has amassed an impressive wealth of detail that is woven into a compelling narrative. He combines the historical background with details of writers' public and private lives in a mode which is both informative and appealing. The dynamism of the narrative is enhanced by frequent dramatic scenes, which capture moments in writers' lives as well as history in the making, while also stressing the role of chance and coincidence in private biographies and public history.

Cold Warriors proceeds chronologically, with subsequent parts corresponding to stages in the Cold War, from Part I: Spain, to Part VIII: Unravelling. Havel is presented in the final part as one of those "cold warriors" who lived to see the end of the Cold War and were fortunate enough to share in the triumph of the side they had steadfastly supported. Overall, Cold Warriors is structured as a plot leading to a happy ending: the collapse of the Soviet Union. The assertion of the triumph of the West inevitably brings to mind Francis Fukuyama's much-debated essay "The End of History?" (1989), in which the author argued that "viable systematic alternatives" to economic and political liberalism had become exhausted. Fukuyama suggested that " $[\mathrm{w}]$ hat we may be witnessing is not just the end of the Cold War, or the passing of a particular period of postwar history, but the end of history as such: that is, the end point of mankind's ideological evolution and the universalization of Western liberal democracy as the final form of human government" (1989: 1). However, writing twenty years later, White does not wish to end on a note which must sound naively optimistic. The Epilogue counterpoints the hopeful resolution of the prolonged conflict with a catalogue of recent, disquieting developments in global politics, among them the threat of terrorism and the re-emergence of Russian imperialism and autocratic tendencies, which have resulted in renewed global divisions and ideological rivalry. The author concludes that even though literature is unlikely ever to play the vital role it did during the Cold War, it has evidently retained some power, which is, sadly, proved by the censorship and harassment that writers in some countries still have to endure.

\section{Bibliography}

Fukuyama, Francis 1989. "The End of History?". The National Interest 16 (Summer): 1-18.

Ker, Ian 2003. The Catholic Revival in English Literature, 1845-1961: Newman, Hopkins, Belloc, Chesterton, Greene, Waugh. Notre Dame, Ind.: University of Notre Dame Press.

Pryce-Jones, David 2019. "War of Words". National Review, 9 September 2019: 39-40.

Scott-Smith, Giles [\&] Joes Segal 2012. "Introduction: Divided Dreamworlds? The Cultural Cold War in East and West". In: Peter Romijn [\&] Giles Scott-Smith [\&] Joes Segal (eds.). Divided Dreamworlds?: The Cultural Cold War in East and West. Amsterdam: Amsterdam University Press. 1-9.

Swift, Jonathan 1933 [1704]. The Battle of the Books. In: Gulliver's Travels; A Tale of a Tub; Battle of the Books, etc. London: Oxford University Press and Humphrey Milford. 537-572.

White, Duncan 2019. Cold Warriors: Writers Who Waged the Literary Cold War. London: Little, Brown. 